\title{
Challenges in modelling of water quantity and quality in two contrasting meso-scale catchments in Poland
}

\author{
Paweł MARCINKOWSKI ${ }^{1) \text { ABCDEF }}{ }^{\text {, Mikołaj PINIEWSKI }}{ }^{\text {1), 2) ABCDEF, }}$ \\ Ignacy KARDEL ${ }^{1)}$ ABCDF, Raghavan SRINIVASAN ${ }^{3)}$, \\ Tomasz OKRUSZKO ${ }^{1) \mathrm{DE}}$
}

\footnotetext{
${ }^{1)}$ Warsaw University of Life Sciences - SGGW, Department of Hydraulic Engineering, Warsaw, Nowoursynowska 159, 02-776 Warsaw, Poland; e-mail: P.Marcinkowski@levis.sggw.pl, M.Piniewski@levis.sggw.pl, I.Kardel@levis.sggw.pl, T.Okruszko@levis.sggw.pl

2) Potsdam Institute for Climate Impact Research, Potsdam, Germany

3) Texas A\&M University, Texas Agricultural Experimental Station, Spatial Science Laboratory; e-mail: r-srinivasan@tamu.edu
}

For citation: Marcinkowski P., Piniewski M., Kardel I., Srinivasan R., Okruszko T. 2016. Challenges in modelling of water quantity and quality in two contrasting meso-scale catchments in Poland. Journal of Water and Land Development. No. 31 p. 97-111. DOI: 10.1515/jwld-2016-0040.

\begin{abstract}
This study presents an application of the SWAT model (Soil and Water Assessment Tool) in two meso-scale catchments in Poland (Upper Narew and Barycz), contrasting in terms of human pressures on water quantity and quality. The main objective was multi-variable and multi-site calibration and validation of the model against daily discharge, sediment and nutrient loads as well as discussion of challenges encountered in calibration phase. Multi-site calibration and validation gave varied results ranging from very good (daily discharge) to acceptable (sediment, nitrogen and phosphorus loads in most of gauges) and rather poor (individual gauges for all variables) in both catchments. The calibrated models enabled spatial quantification of water yield, sediment and nutrient loads, indicating areas of special concern in terms of pollution, as well as estimation of contribution of pollution from different sources, indicating agriculture as the most important source in both catchments. During the calibration process a number of significant issues were encountered: (i) global vs. local parametrization, (ii) simulation of different pools of water quality parameters in reservoirs and streams and (iii) underestimation of $\mathrm{NO}_{3}-\mathrm{N}$ loads in winter due to farmers practices. Discussion of these issues is hoped to aid SWAT model users in Poland in a deeper understanding of mechanisms of multi-variable and multi-site calibration.
\end{abstract}

Key words: model calibration, model validation, nutrients, sediment, SWAT model, water quality modelling, water quantity modelling

\section{INTRODUCTION}

Water quantity and quality modelling using catchment scale, dynamic models has become very popular during past two decades [GAO, LI 2014]. One of the most popular models is Soil and Water Assessment Tool (SWAT) which was applied in Europe across a range of spatial scales: from the whole conti- nent [ABBASPOUR et al. 2015], to largest river basins [ČERKASOVA et al. 2016; PAGLIERo et al. 2014; PINIEWSKI et al. 2016], meso-scale catchments [OSTOJSKI et al. 2014; PINIEWSKI et al. 2015] and small catchments [BRZOZOWSKI et al. 2011; MARCINKOWSKI et al. 2013; MOLINA-NAVARRO et al. 2014; SMARZYŃSKA, MiATKOWSKI 2016; ŚMIETANKA 2014]. An increasing interest in the model triggers more com- 
plex and challenging applications, especially concerning implementation of new remote sensing techniques and datasets [AL-DOUSARI et al. 2010] or more detailed multi-site and multi-variable calibration approach [WOZNICKI et al. 2016]. Since eutrophication of water bodies and excessive erosion are major environmental problems worldwide, many SWAT applications are oriented on evaluating various measures, e.g. Best Management Practices (BMPs) in agriculture [DAKHLALla, PARAJULi 2016; SHESHUKOV et al. 2016], or stressors such as climate change [PINIEWSKI et al. 2014]. Thus, the results are valuable for the environmental policy and decision making process. However, attempts of developing models at high spatial resolution bring many difficulties and technical issues, especially visible at the stage of model calibration and validation. Hence, the aim of this study was: (i) to perform a multi-variable and multisite calibration and validation of the SWAT model in two contrasting meso-scale catchments in Poland (Upper Narew and Barycz) (ii) indication and general discussion of challenges encountered in different phases of the modelling work, but notably in calibration. In contrast to many papers in which modelling results are only success stories, for example with good fit-to-observations but low fit-to-reality (see VAN GRIENSVEN et al. [2012]), we want to present a more critical and balanced view, indicating areas where either the model, the approaches used for modelling or the input data still need major improvements.

\section{MATERIALS AND METHODS}

\section{STUDY AREA}

The study was conducted in two catchments located in north-eastern (Upper Narew) and southwestern (Barycz) Poland (Fig. 1). They are subcatchments of two large Polish river basins (Vistula and Odra). The Upper Narew River and the Barycz River drain areas of $4231 \mathrm{~km}^{2}$ and $5522 \mathrm{~km}^{2}$, respectively. Mean annual precipitation total, equal to 670 $\mathrm{mm}$ in the Upper Narew catchment, is slightly higher compared to the Barycz catchment $(630 \mathrm{~mm})$. Mean annual air temperature equals $7.1^{\circ} \mathrm{C}$ and $8.3^{\circ} \mathrm{C}$ for the Upper Narew and the Barycz, respectively. Both catchments lie on the Polish Plain and are characterized by a flat relief. The elevation varies from 105 to $259 \mathrm{~m}$ a.s.l. (152 on average) in the Upper Narew catchment and from 69 to $282 \mathrm{~m}$ a.s.l. (127 on average) in the Barycz catchment. In both catchments prevailing class of soils are sands and loamy sands and heavy impervious soils are rare. Total area of forests is comparable in both catchments and equals to $43.6 \%$ in the Upper Narew and $38.9 \%$ in the Barycz. Thus, both studied catchments are fairly similar in terms of climatic and physiographic conditions, although the Upper Narew has more continental climate. In contrast, they are on the extreme opposite ends in terms of human dimension: population and its pressures on water quantity and quality. In the Barycz catchment population is around 490 thou-

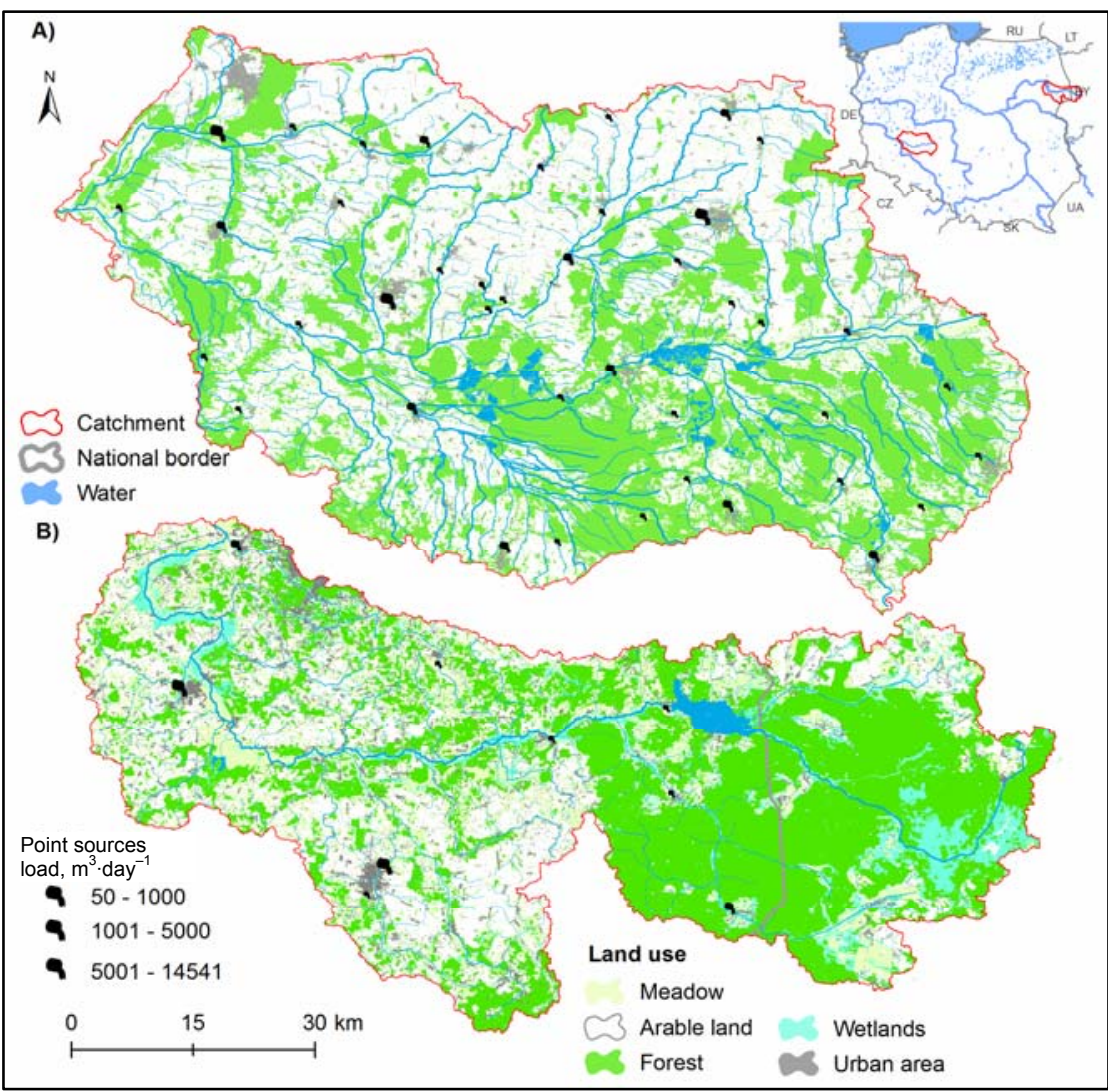

Fig. 1. Location of investigated catchments: A) the Upper Narew catchment, B) the Barycz catchment; source: own elaboration sands which gives a population density equal to 89 persons $\cdot \mathrm{km}^{-2}$ and in the Upper Narew (excluding the Belarusian part of the catchment) 114 thousands and 36 persons $\cdot \mathrm{km}^{-2}$ respectively [GUS 2015]. The Upper Narew is characterized by extensive agriculture, with average fertilizer rates of 55 $\mathrm{kg} \cdot \mathrm{ha}^{-1}$ of nitrogen and 11.6 $\mathrm{kg} \cdot \mathrm{ha}^{-1}$ of phosphorus (calculations based on National Agricultural Census 2010) and a small (11) number of wastewater treatment plants (WWTPs) contributing loads directly to streams (94 $\mathrm{Mg} \cdot \mathrm{year}^{-1}$ of sediment, $116,074 \mathrm{~kg} \cdot$ year $^{-1}$ of total nitrogen and $8,904 \mathrm{~kg} \cdot$ year $^{-1}$ of total phosphorus). In the $\mathrm{Ba}-$ rycz catchment the agriculture is predominantly intensive ( 87 and $16 \mathrm{~kg} \cdot \mathrm{ha}^{-1}$ of nitrogen and phosphorus fertilizer rates, respectively) and the number of WWTPs (39) generates significantly higher pollution 
loads $\left(1,664 \mathrm{Mg} \cdot \mathrm{year}^{-1}\right.$ of sediment, 262,251 kg.year ${ }^{-1}$ of total nitrogen and $45,270 \mathrm{~kg} \cdot \mathrm{year}^{-1}$ of total phosphorus). Despite the fact that the number of WWTPs in Poland has been steadily increasing since early 1990s, still many rural areas are not connected to them and their inhabitants have been using either cesspits or (more recently) on-site WWTPs, called septic tanks. The population size not connected to WWTPs is also much higher in the Barycz than in the Upper Narew $\left(0.21\right.$ persons $\mathrm{km}^{-2}$ compared to 0.04 persons $\mathrm{km}^{-2}$; estimated based on GUS for the year 2000). The major difference in land cover distribution is visible in the share of grassland and arable land: 18 and $23 \%$ in the Upper Narew, and 9 and $47 \%$, respectively, in the Barycz. Finally, the Upper Narew catchment has one relatively large reservoir (Siemianówka, situated in the upstream part) with a usable capacity (storage capacity between the dead storage level and the flood control level) of $62 \mathrm{mln}$ $\mathrm{m}^{3}$, in contrast to the Barycz catchment that does not have any comparable reservoir. Nevertheless, the Barycz catchment has very significant number of fish ponds whose total area equals to 8,100 ha and their total capacity estimated as $73.1 \mathrm{mln}^{3}$ surpasses the capacity of the Siemianówka reservoir. Total capacity of fish ponds present in the Upper Narew catchment (upstream of the Narew National Park) equals $4 \mathrm{mln} \mathrm{m}^{3}$.

\section{MODELLING TOOL}

SWAT is a process-based, semi-distributed, continuous-time model simulating the movement of water, sediment, and nutrients on a catchment scale with a daily time step. The basic calculation unit - hydrologic response unit (HRU) is created by an overlay of land use, soil, and slope maps. Water balance and water quality components are computed separately for each HRU and aggregated at the sub-basin level and routed through the stream network to the main outlet to obtain the total flows and loadings for the river ba$\sin$ [NEITSCH et al. 2011].

In this study, potential evapotranspiration (PET) was estimated using Hargreaves method [HARGREAVES 1982], surface runoff was calculated using the modified USDA Soil Conservation Service (SCS) curve number method and channel routing was computed using a Muskingum method [OVERTON 1966]. Snow-melt estimations are based on the degree-day method in the model. Erosion and sediment yield are calculated for each HRU using the Modified Universal Soil Loss Equation (MUSLE) [WILliams, BERNDT 1977]. Plant growth model adapted in SWAT, based on EPIC [WILLIAMS 1990], is used to assess the removal of water and nutrients from the root zone, transpiration, and biomass/yield production. The in-stream kinetics used in SWAT for nutrient routing is adapted from QUAL2E [BROWN, BARNWELL 1987].

\section{MODEL SETUP}

Table 1 lists all major data items and their sources used to create the SWAT model setup of the Upper Narew and Barycz catchments. Throughout the whole process of developing the model setups an attempt was made to use the same data sources and approaches for both catchments. Nevertheless, since $27 \%$ of the upstream part of the Upper Narew lies in Belarus (Fig. 1), for this part data from various sources usually characterized by lower resolution had to be used.

Table 1. Data items and sources used to create the SWAT model setup of the Upper Narew and Barycz catchments

\begin{tabular}{|c|c|c|}
\hline Data type & Source & Resolution/scale \\
\hline DEM PL & CODGiK & horizontal $10 \mathrm{~m}$ \\
\hline DEM BY & SRTM v4.1 (NASA) & horizontal $90 \mathrm{~m}$ \\
\hline Rivers and lakes PL & $\begin{array}{l}\text { MPHP2010 } \\
\text { (IMGW-PIB) }\end{array}$ & $1: 10,000$ \\
\hline Land Cover PL & $\begin{array}{l}\text { Landsat } 8 \\
\text { CLC } 2006 \text { (GDOS) }\end{array}$ & $\begin{array}{l}30 \mathrm{~m} \\
100 \mathrm{~m}\end{array}$ \\
\hline Land Cover BY & MODIS Landcover & $500 \mathrm{~m}$ \\
\hline Soil map PL & IUNG-PIB & 1:100,000 \\
\hline Soil map BY & HWSD v 1.2 & $1: 1,000,000$ \\
\hline Climate PL/BY & CPLFD-GDPT5 & $5 \mathrm{~km}$ \\
\hline $\begin{array}{l}\text { Atmospheric } \\
\text { deposition of nitrogen }\end{array}$ & GIOŚ & $\begin{array}{l}1 \text { station for the } \\
\text { Upper Narew, } 3 \\
\text { stations for the } \\
\text { Barycz (outside } \\
\text { the catchment) }\end{array}$ \\
\hline Agricultural statistics & GUS & commune level \\
\hline
\end{tabular}

Explanations: $\mathrm{BY}=$ Belarus, $\mathrm{CLC}=$ Corine Land Cover, CODGiK $=$ Central Agency for Geodetic and Cartographic Documentation, CPLFD-GDPT5 = CHASE-PL Forcing Data-Gridded Daily Precipitation \& Temperature Dataset $-5 \mathrm{~km}$ [BEREZOWSKI et al. 2016], DEM = Digital Elevation Model, GDOŚ = General Directorate of the Environmental Protection, GIOŚ = Chief Inspectorate of Environmental Protection, GUS = Central Statistical Office of Poland, HWSD = Harmonized World Soil Database, IMGW-PIB = Institute of Meteorology and Water Management - National Research Institute, IUNG-PIB = Institute of Soil Science and Plant Cultivation - National Research Institute, MPHP = Hydrographic map of Poland, NASA = National Aeronautics, PL = Poland, SRTM = Shuttle Radar Topography Mission.

Source: own elaboration.

In this study a 10-meter resolution Digital Elevation Model (DEM) (created from the ESRI TIN DEM available from CODGiK (Polish Central Geodetic and Cartographic Agency), with mean elevation error of $0.8-2.0 \mathrm{~m}$ ) has been used for automatic catchments delineation. Initial delineation output was manually corrected to account for errors in and the final division of the Upper Narew had 243 sub-basins (average area of $17 \mathrm{~km}^{2}$ ), whereas the Barycz was divided into $503 \mathrm{sub}$-basins (average area of $11 \mathrm{~km}^{2}$ ). Various data sources were used to feature particular land cover classes:

1) The Corine Land Cover (CLC) 2006 layer was used as the primary data source for recognition of water and forests.

2) The (open) drainage ditch layer was used to subdivide the CLC grasslands class into those under 
and beyond the influence of drainage. Based on the available vector layer representing the network of ditches it was assumed that the influence of the drainage ditches occurred within a $100 \mathrm{~m}$ buffer around the ditches.

3) The main crops were featured based on Landsat 8 data (30 $\mathrm{m}$ spatial resolution, temporal resolution $\sim 6$ cloud-free scenes per year in Poland). All available Landsat scenes in the vegetation season of the selected period (2014) were gathered and for each scene vegetation indices (e.g. NDVI Normalized Difference Vegetation Index) were calculated. This step also required spectral calibration of individual scenes. The NDVI time series and the original spectral bands of Landsat were merged and a classification model (Random Forest) of the merged dataset was trained based on the field data (vegetation type, plant species). Afterwards the model was applied and validated for the whole study areas.

4) For the Upper Narew a part of the catchment land use beyond the Polish border was attributed based on global MODIS Land cover map.

5) Urban areas were featured based on Landsat 8 classification and additionally by the Open-StreetMap.

In order to improve the representation of the crop structure originating from Landsat 8 classification within the model setup commune-level data from the Central Statistical Office [GUS 2010], for each catchment were used to meet the actual areas occupied by crops. In SWAT crop distribution might be reflected by .mgt table where operation schedules for each crop are characterized and applied for the particular area of the catchment. Scheduling of crops allows also to implement crop rotation where for each year of rotation different crop may be planted. Statistical data of crop distribution from GUS allowed to reflect the actual occupation area of each crop by modifying . $m g t$ table. Additionally, data from Regional Chemical-Agricultural Station in Białystok and Wrocław (OSChR) containing survey-based information about crop rotation declared by farmers in the Podlaskie and Dolnośląskie voivodship was used to reflect the actual crop rotation distribution in each catchment. The final distribution of land cover classes including the crop distribution from the statistical data is shown in Table 2.

The numerical soil map from the Institute of Soil Science and Plant Cultivation (IUNG-PIB) - within the country borders and Harmonized World Soil Database (HWSD) in the Belarusian part of the Upper Narew catchment, allowed to distinguish 27 soil classes for the Barycz catchment and 28 classes for the Upper Narew catchment. Overlaying of land cover map, soil map, and slope classes (threshold values of 3.5 and $3 \%$ for the Upper Narew and Barycz, respectively) resulted in creation of 4509 HRUs in the Upper Narew catchment and 8569 in the Barycz catchment.
Table 2. Land cover distribution in the Upper Narew and Barycz catchment

\begin{tabular}{|l|c|c|}
\hline \multirow{2}{*}{ Landcover } & \multicolumn{2}{|c|}{ Percentage share } \\
\cline { 2 - 3 } & $\begin{array}{c}\text { the Upper Narew } \\
\text { catchment }\end{array}$ & $\begin{array}{c}\text { the Barycz } \\
\text { catchment }\end{array}$ \\
\hline Rye (RYE) & 1.8 & 13.3 \\
\hline Winter Wheat (WWHT) & 5.3 & 13.9 \\
\hline Spring Wheat (SWHT) & 5.7 & 1.4 \\
\hline Oats (OATS) & 4.0 & 2.0 \\
\hline Barley (BARL) & 3.1 & 8.5 \\
\hline Corn Silage (CSIL) & 1.1 & 3.5 \\
\hline Spring Canola-Polish (CANP) & - & 3.1 \\
\hline Potato (POTA) & 2.2 & 1.0 \\
\hline Tall Fescue (FESC) & 10.7 & 5.0 \\
\hline Tall Fescue (FES2) & 7.5 & 4.5 \\
\hline Forest-Evergreen (FRSE) & 21.5 & 18.3 \\
\hline Forest-Deciduous (FRSD) & 9.9 & 5.6 \\
\hline Forest-Mixed (FRST) & 12.5 & 15.0 \\
\hline Residential-High Density (URHD) & 1.0 & 1.2 \\
\hline Residential-Med/Low Density & 4.9 & 2.3 \\
\hline (URML) & 0.6 & 1.4 \\
\hline Water (WATR) & 8.2 & - \\
\hline Wetlands-Non-Forested (WETN) & & \\
\hline
\end{tabular}

Source: own elaboration.

Precipitation and temperature data were acquired from CHASE-PL Forcing Data-Gridded Daily Precipitation \& Temperature Dataset - $5 \mathrm{~km}$ (CPLFD-GDPT5) [BEREZOWSKI et al. 2016]. It consists of 1951-2013 daily minimum and maximum air temperatures and precipitation totals interpolated onto a $5 \mathrm{~km}$ grid based on daily meteorological observations coming mainly from the Institute of Meteorology and Water Management (IMGW-PIB; Polish stations). As shown by PINIEWSKI, SZCZEŚNIAK [2015] the use of interpolated climate data in the SWAT model leads to an increase in discharge calibration statistics. CPLFDGDPT5 dataset (minimum and maximum air temperatures and precipitation) were interpolated onto subbasins prior to their use in SWAT.

Commune-level statistical data were used to determine mineral fertilizer use and livestock population in order to impose a spatial variability of fertilizer rates in the model setup. The livestock population data were used to calculate the amount of available organic fertilizer (manure or slurry) based on predefined table from the Code of Good Agricultural Practice [MRiRW, MŚ 2004]. As a result correction factors for fertilizer rates that were originally defined in management schedules were defined for the subbasins that overlapped with different communes. In each HRU fertilizer rate in the operation schedules was adjusted using the calculated correction factors which allowed for obtaining a more spatially realistic fertilizer use representation.

WWTPs in studied catchments were defined in the model setup only when the total volume of daily wastewater discharge exceeded $25 \mathrm{~m}^{3} \cdot$ day $^{-1}$. For each WWTP, discharge and nutrient loads were expressed as mean yearly or mean monthly values depending on the available data. These values, likewise the addi- 
tional data i.e. date and type of technological modernization, were obtained directly from plant operators by surveys conducted during field visits in summer 2014 or by electronic surveys. The response has been received from the majority of largest WWTPs in each catchment (12 and 3 for the Barycz and the Upper Narew, respectively). Average sediment and nutrients loads contributed to streams in each catchment from WWTPs was presented in subsection "Study area".

The septic systems function of SWAT was used to model the effect of pollution loads coming from population not connected to WWTPs (using cesspits or septic tanks, with or without sub-surface drainage). Septic systems were identified based on communelevel data on the number of people not connected to WWTPs as for the year 2000 [GUS 2000]. For the purpose of defining SWAT septic input data it was assumed that one system has an area of $100 \mathrm{~m}^{2}$ and supports 4 people. Then, for each commune, the URML land use class was converted to septic system if all three criteria were fulfilled: (1) situated within a distance of more than $10 \mathrm{~km}$ from the nearest WWTP, (2) with permeable soils (i.e. in areas where such systems are permitted) and (3) with very low density (scattered) built-up areas (i.e. areas for which construction of the sewer pipes is unprofitable). As a result of this process, the following densities of septic tanks were obtained: $6.8 \mathrm{~m}^{2} \cdot \mathrm{ha}^{-1}$ for the Upper Narew and $12.6 \mathrm{~m}^{2} \cdot \mathrm{ha}^{-1}$ for Barycz.

In its current version, the SWAT model does not have any function that would allow for a reliable representation of the water management of cyprinid fish pond systems in the Polish conditions. Due to a high abundance of fish ponds in the Barycz catchment, two out of seven flow time series that were most influenced by fish ponds (the Barycz River at Łaki and Osetno) have undergone a naturalization procedure prior to their use for calibration and validation. Naturalization followed general guidelines used in water management balances in Poland [TYSZEWSKI et al. 1997]. A spreadsheet model of fish pond water management was created, taking into account precipitation and evaporation as two major natural water budget components as well as human-associated components: filtration losses, water withdrawal (filling the ponds) and water discharge (emptying the ponds). The main simulated variable was the actual total storage of ponds in selected catchment. The pond parameters (approximate operation schedule, sources of withdrawals, pond areas and depths, filtration rate) were acquired from "Stawy Milickie" company, from the Hydrographic Division of Poland (MPHP) map and from available literature [DRABIŃSKI 2010]. Additionally, flow alterations were identified based on the comparison of impacted hydrographs with hydrographs from the nearby gauges not impacted by pond activity. The magnitude of withdrawal was dependent on the relation between actual flow and the minimum hydrobiological flow (known as "przepływ nienaruszalny" in Poland). The naturalized flow time series were higher than the observed time series in the period January-August (filling period), lower in September and October (emptying period) and almost unchanged in November and December. Since the model of the Barycz catchment was calibrated against these naturalized discharges, the simulated discharges reflect the natural conditions, and not the conditions actually observed in the presence of fish ponds. In consequence, also the fish pond effects on water quality are neglected here.

\section{MULTI-SITE CALIBRATION}

Both catchments represent areas with significant variability in spatial and temporal characteristics and the observed data are available at multiple locations within the study area. Hence, a complex calibration and validation strategy was implemented as the most appropriate [DAGGUPATI et al. 2015]. Calibration phase was conducted in SWAT-CUP - program that allows to optimize the SWAT model using a number of different algorithms [ABBASPOUR 2015]. In this study SWAT-CUP version 2012 5.1.6 and the SUFI-2 algorithm (Sequential Uncertainty Fitting Procedure Version 2) were applied. It is a comprehensive stochastic algorithm which contains elements of calibration and uncertainty analysis. The Kling-Gupta efficiency (KGE) [GUPTA et al. 2009] was used as an objective function. The KGE can range from $-\infty$ to 1 , where 1 is optimal.

$$
K G E=1-\sqrt{(r-1)^{2}+(\alpha-1)^{2}+(\beta-1)^{2}}
$$

where: $r=$ linear regression coefficient (correlation term); $\alpha=$ ratio of simulated over observed standard deviation (variability term); $\beta=$ ratio of simulated over observed mean (bias term).

Additionally percent bias (PBIAS) was tracked which measures the average tendency of the modelled data to be larger or smaller than their observed counterparts. Positive values indicate model underestimation bias, and negative values indicate model overestimation bias.

There were ten flow gauges (data acquired from the IMGW-PIB) and nine water quality monitoring stations (concentration data acquired from the General Inspectorate of Environmental Protection) in the Upper Narew that were used in the calibration and validation. Likewise, in the Barycz there were seven flow gauges and eight water quality monitoring stations (Fig. 2). Calibration was divided into four steps, (1) daily discharge, (2) total suspended sediment loads, (3) nitrogen loads (nitrate-nitrogen and total pools), (4) phosphorus loads (phosphate and total pools). Tables 3-6 show the list, definitions and ranges of parameters used for calibration. Selected parameters represent the following processes: evaporation, groundwater and surface flow for hydrology; erosion and settling for sediment; denitrification, nitrification, 


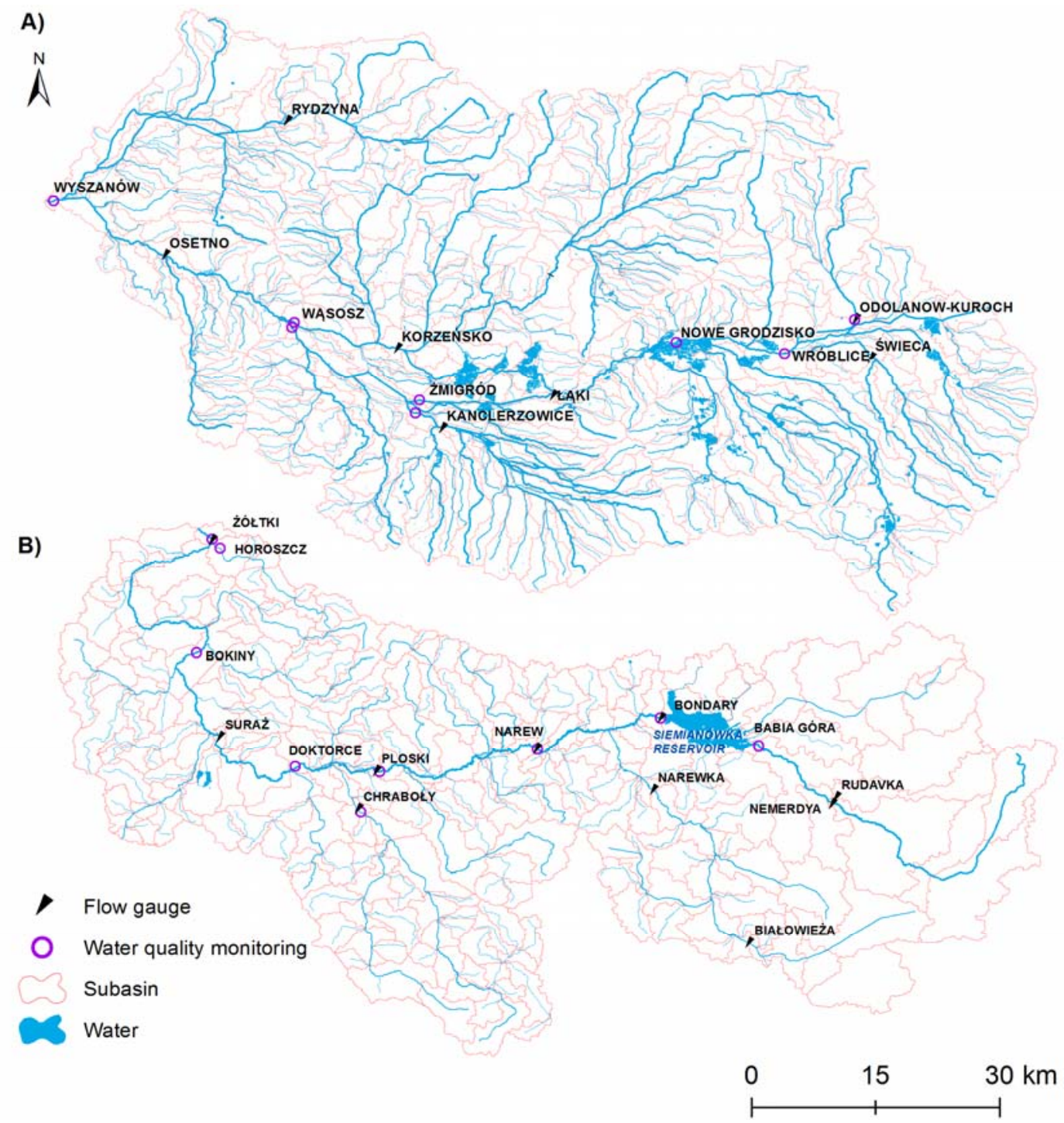

Fig. 2. Monitoring points location in the studied catchments: A) Upper Narew, B) Barycz; source: own elaboration

percolation, uptake, settling and decay for nutrients. The minimum and maximum values presented in these tables are related to extreme values of parameters across the calibrated gauges and water quality monitoring points for each variable. Selection of the parameters set was made based on previous applications of the SWAT model under Polish conditions [PINIEWSKI et al. 2014; PINIEWSKI et al. 2015; MARCINKOWSKI et al. 2013] and on the sensitivity analysis performed in both catchments. An important thing in the context of multi-site calibration is the fact that parameters are either global (i.e. one value for the whole catchment) or local (i.e. one value per subbasin or HRU).

The frequency of water quality sampling was approximately one per month, however due to very low correlations between water quality variables and discharge, no regression-based method was justified to be used and hence the model was calibrated against daily (discrete, not continuous) contaminant loads. The average daily loads $\left(\mathrm{kg} \cdot \mathrm{day}^{-1}\right)$ on the sampling dates were calculated based on simulated daily discharge data $\left(\mathrm{m}^{3} \cdot \mathrm{day}^{-1}\right)$ at the sub-basin in which water quality monitoring station was located. For the both catchments the calibration period for discharge was from 1976 to 1985, and the validation period was from 1986 to 1991 , whereas for the water quality variables these periods were set to 1999-2005 and 20062010 , respectively. Selection of different periods for discharge and water quality was due to the fact that periods were optimized in terms of having the highest number of observation record available. Many flow gauging stations were closed in 1990s, which forced selection of earlier years. For the calibration and validation period the same land use map as the one described in the section "Model setup" was used. SWAT, as most hydrological models, does not incorporate a dynamic land use map. The available Land Use Update function has very limited functionality and was not used in this case. The reasoning was that the uncertainty related to this imperfect approach is relatively low. To justify this land cover changes 
Table 3. Discharge calibration parameters - definitions and ranges

\begin{tabular}{|c|c|c|c|c|c|}
\hline \multirow{2}{*}{ Name } & \multirow{2}{*}{ Definition } & \multicolumn{2}{|c|}{ Upper Narew } & \multicolumn{2}{|c|}{ Barycz } \\
\hline & & $\min$ & $\max$ & $\min$ & $\max$ \\
\hline $\mathrm{v} \quad$ SURLAG.hru & surface runoff lag coefficient & 0.12 & 1.77 & 0.09 & 0.23 \\
\hline $\mathrm{v}$ _SUB_TIMP.sno & snow pack temperature lag factor & 0.07 & 0.55 & 0.07 & 0.29 \\
\hline V_SUB_SMTMP.sno & snow melt base temperature, ${ }^{\circ} \mathrm{C}$ & -2.15 & 0.89 & - & - \\
\hline $\mathrm{r} \_\mathrm{CN} 2 . \mathrm{mgt}$ & initial SCS runoff curve number for moisture condition II & 0.02 & 0.13 & -0.11 & 0.15 \\
\hline r_ALPHA_BF.gw & baseflow alpha factor, days $^{-1}$ & 0.05 & 0.13 & 0.04 & 0.28 \\
\hline $\mathrm{r} \quad$ GW_DELAY.gw & groundwater delay time, days & 20.31 & 196.36 & 8.15 & 289.75 \\
\hline V__GWQMN.gw & $\begin{array}{l}\text { threshold depth of water in the shallow aquifer required for re- } \\
\text { turn flow to occur, } \mathrm{mm} \mathrm{H}_{2} \mathrm{O}\end{array}$ & 117.5 & 735.81 & 147 & 941 \\
\hline r_GW_REVAP.gw & groundwater "revap" coefficient & 0.037 & 0.154 & 0.027 & 0.124 \\
\hline $\mathrm{r} \quad$ RCHRG_DP.gw & deep aquifer percolation fraction & 0.02 & 0.174 & 0.082 & 0.14 \\
\hline $\mathrm{v}$ ESCO.hru & soil evaporation compensation factor & 0.82 & 0.98 & 0.7 & 0.95 \\
\hline $\mathrm{v}$ _EPCO.hru & plant uptake compensation factor & 0.14 & 0.79 & 0.33 & 0.98 \\
\hline $\mathrm{r} \_\mathrm{CH} \_\mathrm{N} 2 . \mathrm{rte}$ & Manning's $n$ value for the main channel & 0.03 & 0.07 & 0.06 & 0.11 \\
\hline $\mathrm{r} \quad \mathrm{CH} \mathrm{N}_{-} \mathrm{N} 1 . \mathrm{sub}$ & Manning's $n$ value for the tributary channel & 0.04 & 0.09 & 0 & 0 \\
\hline $\begin{array}{|ll|}\text { r } & \text { SOL Z.sol } \\
\end{array}$ & depth from soil surface to bottom of layer, $\mathrm{mm}$ & - & - & -0.2 & 0.17 \\
\hline r $\quad$ SOL_K.sol & saturated hydraulic conductivity, $\mathrm{mm} \cdot \mathrm{hr}^{-1}$ & -0.76 & 1.12 & - & - \\
\hline r $\quad$ SOL_BD.sol & moist bulk density, $\mathrm{g} \cdot \mathrm{cm}^{-3}$ & -0.29 & 0.35 & -0.03 & 0.08 \\
\hline $\mathrm{r}$ _SOL_AWC.sol & available water capacity of the soil layer, $\mathrm{mm} \mathrm{H}_{2} \mathrm{O} \cdot \mathrm{mm}^{-1}$ soil & -0.26 & 0.09 & -0.07 & 0.06 \\
\hline $\mathrm{v} \quad$ SLSOIL.hru & slope length for lateral subsurface flow, $\mathrm{m}$ & 34.2 & 93.8 & 26.5 & 60.6 \\
\hline
\end{tabular}

Explanations: $\mathrm{r}_{-}=$indicates relative change; $\mathrm{v}_{-}=$indicates replacement by a new value; suffixes. $\mathrm{gw}$, hru, etc. $=$ SWAT file extensions.

Source: own study.

Table 4. Sediment calibration parameters - definitions and ranges

\begin{tabular}{|c|c|c|c|c|c|}
\hline \multirow{2}{*}{ Name } & \multirow{2}{*}{ Definition } & \multicolumn{2}{|c|}{ Upper Narew } & \multicolumn{2}{|c|}{ Barycz } \\
\hline & & $\min$ & $\max$ & $\min$ & $\max$ \\
\hline V__PRF_BSN.bsn & peak rate adjustment factor for sediment routing in the main channel & \multicolumn{2}{|c|}{0.08} & \multicolumn{2}{|c|}{0.99} \\
\hline v_ADJ_PKR.bsn & peak rate adjustment factor for sediment routing in the subbasin & \multicolumn{2}{|c|}{1.69} & \multicolumn{2}{|c|}{0.7} \\
\hline v__SPCON.bsn & $\begin{array}{l}\text { linear parameter for calculating the maximum amount of sediment } \\
\text { that can be reentrained during channel sediment routing }\end{array}$ & \multicolumn{2}{|c|}{0.0017} & \multicolumn{2}{|c|}{0.000123} \\
\hline V__SPEXP.bsn & $\begin{array}{l}\text { exponent parameter for calculating sediment reentrained in channel } \\
\text { sediment routing }\end{array}$ & \multicolumn{2}{|c|}{1.26} & \multicolumn{2}{|c|}{1.07} \\
\hline v_LAT_SED.hru & sediment concentration in lateral and groundwater flow, $\mathrm{mg} \cdot \mathrm{l}^{-1}$ & 3.21 & 9.9 & 0.5 & 9.79 \\
\hline $\mathrm{V} \_\mathrm{CH}$ _COV1.rte & channel erodibility factor & 0.52 & 0.76 & 0.003 & 0.78 \\
\hline $\mathrm{v} \_\mathrm{CH}$ & channel cover factor & 0.05 & 0.88 & 0.41 & 0.95 \\
\hline $\mathrm{r}$ _USLE_P.mgt & USLE equation support practice factor & \multicolumn{2}{|c|}{-0.49} & -0.38 & -0.04 \\
\hline r_USLE_K.sol & USLE equation soil erodibility $(\mathrm{K})$ factor & -0.38 & 0.94 & -0.49 & 0.36 \\
\hline V_RES_NSED.res & equilibrium sediment concentration in the reservoir, $\mathrm{mg} \cdot \mathrm{l}^{-1}$ & \multicolumn{2}{|c|}{87.37} & - & - \\
\hline v_RES_D50.res & median particle diameter of sediment, $\mu \mathrm{m}$ & \multicolumn{2}{|c|}{15.57} & - & - \\
\hline
\end{tabular}

Explanations as in Tab. 3.

Source: own study.

Table 5. Nitrogen calibration parameters - definitions and ranges

\begin{tabular}{|c|c|c|c|c|}
\hline \multirow{2}{*}{ Name } & \multirow{2}{*}{ Definition } & \multirow{2}{*}{$\begin{array}{l}\text { Upper } \\
\text { Narew }\end{array}$} & \multicolumn{2}{|c|}{ Barycz } \\
\hline & & & $\min$ & $\max$ \\
\hline \begin{tabular}{ll|}
$\mathrm{v}$ & ERORGN.hru \\
\end{tabular} & organic $\mathrm{N}$ enrichment ratio for loading with sediment & 2.64 & 1.77 & 2.92 \\
\hline v BIOMIX.mgt & biological mixing efficiency & 0.39 & 0.19 & 0.56 \\
\hline $\mathrm{v}$ _HLIFE_NGW.gw & half-life of nitrate in the shallow aquifer, days & 47.06 & 98.21 & 149.76 \\
\hline $\mathrm{v} \quad$ SOL ORGN.chm & initial organic $\mathrm{N}$ concentration in the soil layer, $\mathrm{mg} \mathrm{N} \cdot \mathrm{kg}^{-1}$ soil, dry weight & 193.03 & 125.25 & 250.5 \\
\hline r $\quad$ SOL_CBN.sol & organic carbon content, $\%$ soil weight & 0.06 & -0.19 & -0.09 \\
\hline r_RS4.swq & rate coefficient for organic $\mathrm{N}$ settling in the reach at $20^{\circ} \mathrm{C}$, day ${ }^{-1}$ & 0.033 & 0.01 & 0.044 \\
\hline $\begin{array}{lll}\mathrm{r} & \mathrm{RS} 3 . \mathrm{swq} \\
\end{array}$ & benthic source rate for $\mathrm{NH} 4-\mathrm{N}$ in the reach at $20^{\circ} \mathrm{C}, \mathrm{mg} \mathrm{NH}_{4}-\mathrm{N} \cdot\left(\mathrm{m}^{2} \cdot \mathrm{day}\right)^{-1}$ & - & 0.29 & 0.46 \\
\hline $\mathrm{V} \quad$ AI1.wwq & fraction of algal biomass that is nitrogen, $\mathrm{mg} \mathrm{N} \cdot \mathrm{mg} \mathrm{alg}^{-1}$ & 0.077 & - & - \\
\hline $\mathrm{v}$ _CDN.bsn & denitrification exponential rate coefficient & 0.81 & \multicolumn{2}{|c|}{0.67} \\
\hline $\mathrm{v} \quad \mathrm{N}$ UPDIS.bsn & nitrogen uptake by plants distribution parameter & 25.7 & \multicolumn{2}{|c|}{3.5} \\
\hline v CMN.bsn & rate factor for humus mineralization of active organic nutrients & 0.0023 & \multicolumn{2}{|c|}{0.0022} \\
\hline $\mathrm{v}$ SDNCO.bsn & denitrification threshold water content & 0.99 & \multicolumn{2}{|c|}{1.02} \\
\hline $\begin{array}{ll}\mathrm{v} & \text { NPERCO.bsn } \\
\end{array}$ & nitrate percolation coefficient & 0.93 & \multicolumn{2}{|c|}{0.98} \\
\hline $\mathrm{V}$ __NSETLR1.lwq & nitrogen settling rate in reservoir for months IRES1 through IRES2, m·year ${ }^{-1}$ & 0.48 & - & - \\
\hline v_NSETLR2.1wq & $\begin{array}{l}\text { nitrogen settling rate in reservoir for months other than IRES1 through IRES2, } \\
\text { m·year }{ }^{-1}\end{array}$ & -42.57 & - & - \\
\hline $\mathrm{v}$ SHALLST_N.gw & initial concentration of nitrate in shallow aquifer, ppm & - & 5.25 & 9.55 \\
\hline
\end{tabular}

Explanations as in Tab. 3.

Source: own study. 
Table 6. Phosphorus calibration parameters - definitions and ranges

\begin{tabular}{|c|c|c|c|c|}
\hline \multirow{2}{*}{ Name } & \multirow{2}{*}{ Definition } & \multirow{2}{*}{ Upper Narew } & \multicolumn{2}{|c|}{ Barycz } \\
\hline & & & $\min$ & $\max$ \\
\hline V_P_P_UPDIS.bsn & phosphorus uptake distribution parameter & 39.04 & \multicolumn{2}{|c|}{1.5} \\
\hline $\mathrm{v}$ _PPERCO.bsn & phosphorus percolation coefficient, $10 \mathrm{~m}^{3} \cdot \mathrm{Mg}^{-1}$ & 11.73 & \multicolumn{2}{|c|}{16.56} \\
\hline $\mathrm{v} \_$PHOSKD.bsn & phosphorus soil partitioning coefficient, $\mathrm{m}^{3} \cdot \mathrm{Mg}^{-1}$ & 188.44 & \multicolumn{2}{|c|}{118.5} \\
\hline $\mathrm{V}$ _PSP.bsn & phosphorus availability index & 0.09 & \multicolumn{2}{|c|}{0.54} \\
\hline v_CH_OPCO.rte & organic phosphorus concentration in the channel, $\mathrm{ppm}$ & 20.77 & 8.25 & 56.5 \\
\hline v_RS2.swq & $\begin{array}{l}\text { benthic (sediment) source rate for dissolved phosphorus in the reach at } \\
20^{\circ} \mathrm{C}, \mathrm{mg} \text { dissolved } \mathrm{P} \cdot\left(\mathrm{m}^{2} \cdot \text { day }\right)^{-1}\end{array}$ & 0.04 & - & - \\
\hline v_RS5.swq & organic phosphorus settling rate in the reach at $20^{\circ} \mathrm{C}$, day ${ }^{-1}$ & 0.07 & 0.05 & 0.09 \\
\hline V_SOL_ORGP.chm & initial organic $\mathrm{P}$ concentration in soil layer, ppm & 312.7 & 10 & 390 \\
\hline v_ERORGP.hru & phosphorus enrichment ratio for loading with sediment & 0.29 & 0.47 & 3.82 \\
\hline r_GWSOLP.gw & $\begin{array}{l}\text { concentration of soluble phosphorus in groundwater contribution to } \\
\text { streamflow from subbasin, ppm }\end{array}$ & 0.04 & 0.001 & 0.14 \\
\hline v_PSETLR1.lwq & $\begin{array}{l}\text { phosphorus settling rate in reservoir for months IRES1 through IRES2, } \\
\text { m.year }^{-1}\end{array}$ & 0.22 & - & - \\
\hline v_PSETLR2.1wq & $\begin{array}{l}\begin{array}{l}\text { phosphorus settling rate in reservoir for months other than IRES1-IRES2, } \\
m^{\prime} y^{-1}{ }^{-1}\end{array} \\
\end{array}$ & -15.4 & - & - \\
\hline
\end{tabular}

Explanations as in Tab. 3.

Source: own study.

between the CORINE Land Cover 1990 (the oldest available product of this type) and CLC2012 were compared. The analysis showed that the patterns of change in both catchments were similar (agriculture areas converted mainly into artificial surfaces or afforested). However, the rates of change were not very high, not exceeding $5 \%$ in any of the catchments. Previous modelling studies using SWAT in Poland [PINIEWSKI 2012; PINIEWSKI et al. 2014] showed that land use change has considerably lower effect on hydrology than the climate change. Hence, using the actual land use map for calibration and validation of the hydrology of the period 1978-1991, is of course associated with errors but of rather low magnitude.

\section{RESULTS}

\section{CALIBRATION AND VALIDATION}

Multi-site calibration and validation approach implemented in the Upper Narew and the Barycz catchment gave varied results ranging from very good to rather poor for individual monitoring points and variables. Figures 3 and 4 illustrate simulated versus observed flows, sediment load, $\mathrm{NO}_{3}-\mathrm{N}$ and total nitrogen (TN) load and $\mathrm{PO}_{4}-\mathrm{P}$ and total phosphorus (TP) load, at the catchments' outlets, for the calibration period. In general, hydrographs of simulated and measured flows demonstrate periods with underestimated high flow peaks (1979, 1981). Overestimation is noted in terms of simulating low flows in the Barycz catchment (1980-1983) which is not visible in further years when the base flow is underestimated. In the Upper Narew catchment low flows are simulated more accurately and no significant mismatch is observed. For sediment and nutrients simulation in both catchments periods with lower loads are simulated more precisely comparing to high peak loads where under and overestimations during the calibration period are observed. Goodness-

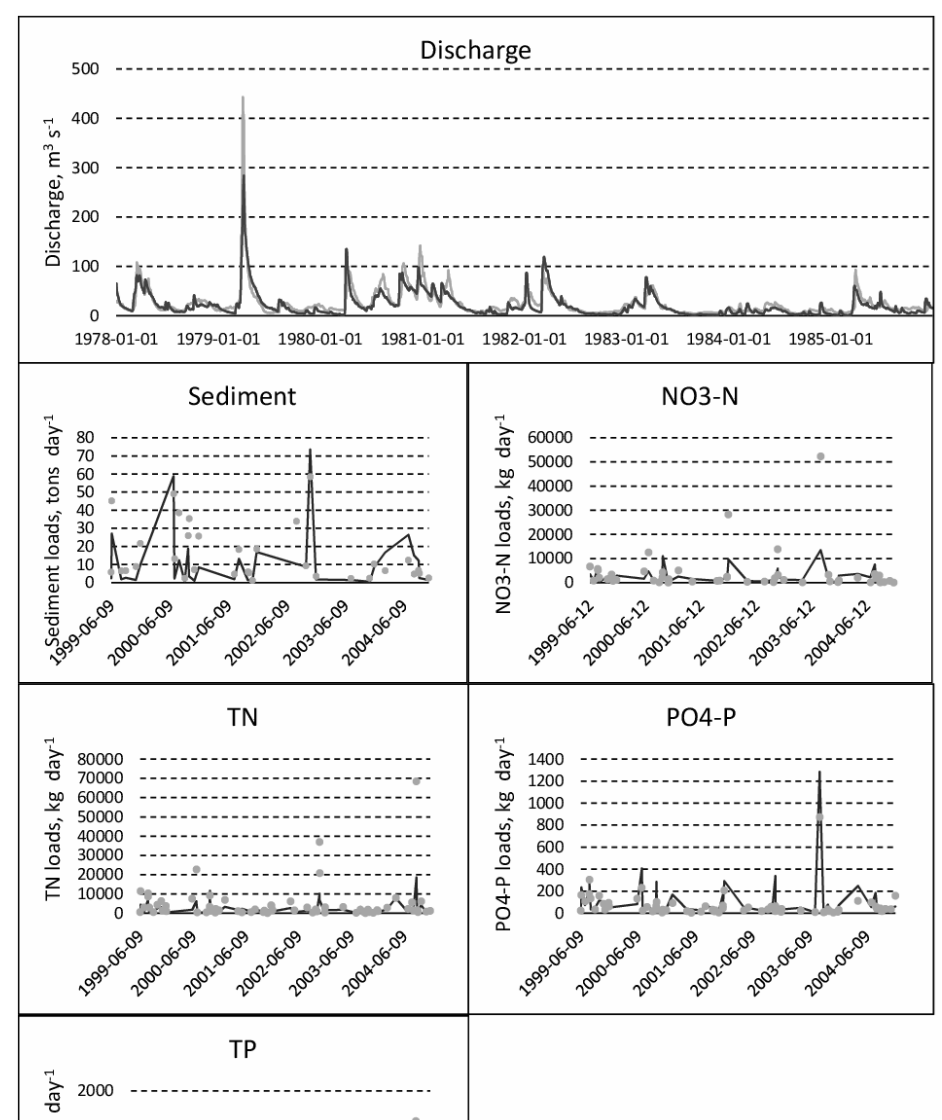

站 1500 -

st 1000 Fig. 3. Calibration plots for selected variables in the Upper Narew catchment (black lines = simulated, grey lines/dots = observed values); $\mathrm{TN}=$ total nitrogen, $\mathrm{TP}=$ total phosphorus; source: own study 


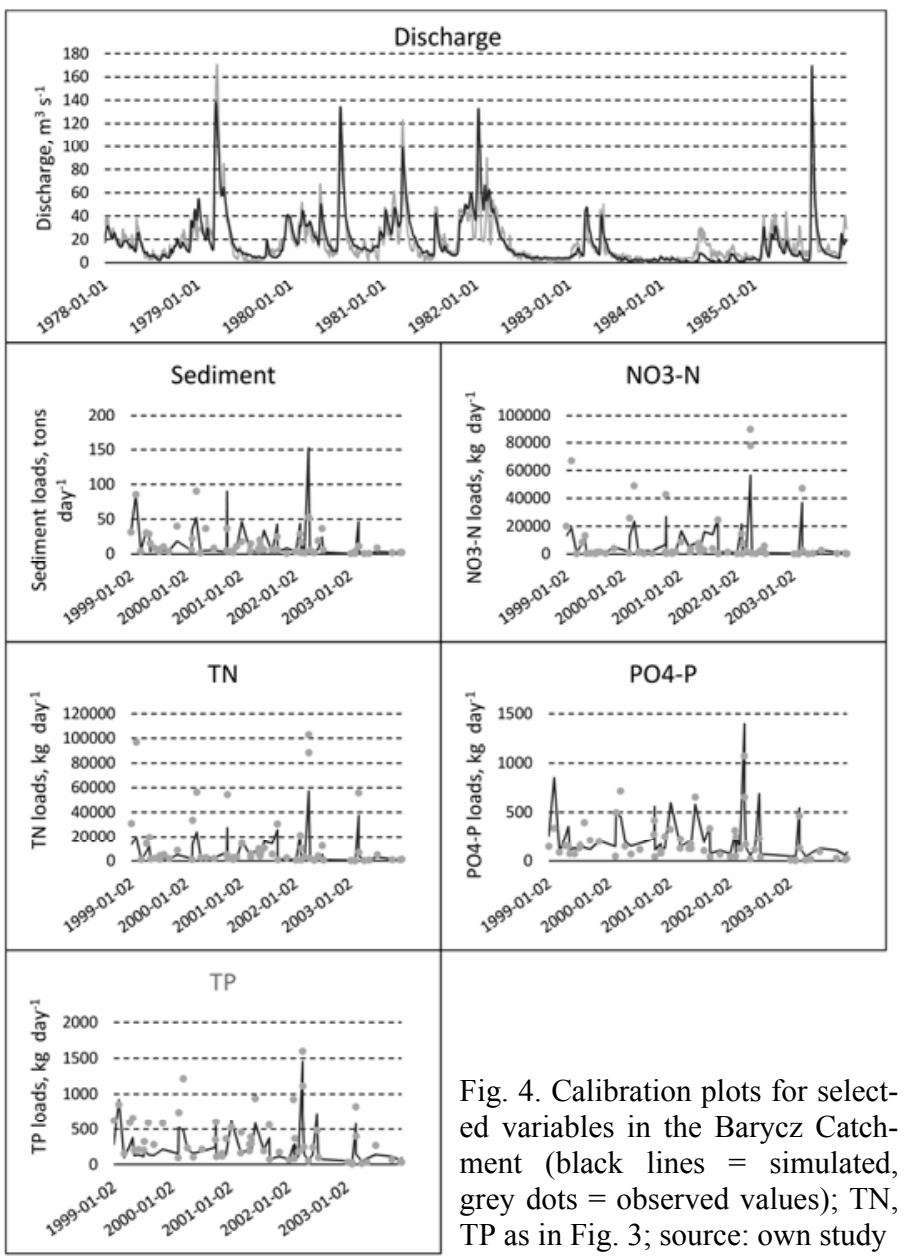

-of-fit measures (Fig. 5, Tab. 7) and interpretation of hydrographs demonstrate good model performance in simulating daily discharge in both catchments for calibration and validation period for all gauging stations. The percent bias (PBIAS) and Kling-Gupta efficiency (KGE) values indicate good model estimations in terms of average flows as well as high peak seasonal flows.

Water quality modelling unlike the quantity, gave overall worse but mostly acceptable results. In general, model validation statistics were slightly worse than calibration. Comparison of statistics between two catchments shows generally higher values for the Barycz than for the Upper Narew catchment. Among the variables, statistics indicate that simulations of phosphorus are better than nitrogen and considering their pools slightly superior for mineral than for total forms. Investigation of PBIAS, KGE and interpretation on graphs lead to general conclusion that nearly for all monitoring points model underestimates contaminants loads especially high seasonal peaks occurring 1-2 times a year.

Multi-site calibration performed in this study used all available monitoring points and datasets and hence for some of them statistics were unsatisfactory. It is clearly visible in Figure 5 presenting box plots of model performance statistics for different variables
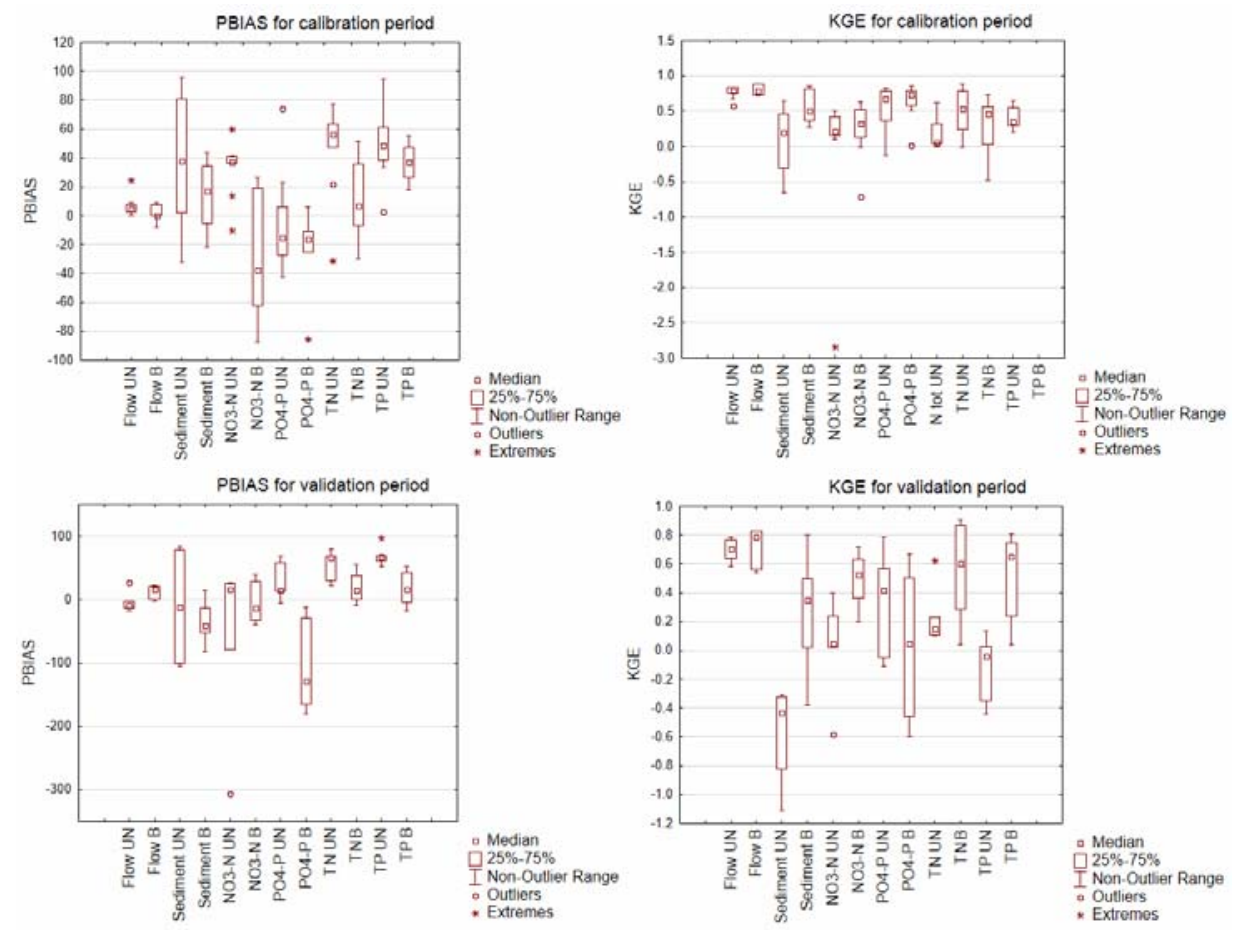

Fig. 5. Calibration and validation percent bias (PBIAS) and Kling-Gupta efficiency (KGE) medians of simulated variables for the Upper Narew (UN) and the Barycz (B) catchment; source: own study 
Table 7. Calibration goodness-of-fit measures at the most downstream monitoring point

\begin{tabular}{|l|c|c|c|c|r|r|r|r|}
\hline \multirow{3}{*}{ Parameter } & \multicolumn{4}{|c|}{ Calibration } & \multicolumn{4}{c|}{ Validation } \\
\cline { 2 - 10 } & Upper Narew & \multicolumn{2}{|c|}{ Barycz } & \multicolumn{2}{|c|}{ Upper Narew } & \multicolumn{2}{|c|}{ Barycz } \\
\cline { 2 - 10 } & PBIAS & KGE & \multicolumn{1}{|c|}{ PBIAS } & KGE & PBIAS & KGE & PBIAS & KGE \\
\hline Flow & 5.4 & 0.79 & 0 & 0.85 & -8.8 & 0.71 & 13.7 & 0.83 \\
\hline Sediment & 27.5 & 0.64 & -21.7 & 0.33 & -15.7 & -0.40 & -52.5 & 0.02 \\
\hline $\mathrm{NO}_{3}$-N & 37.4 & 0.21 & 19.0 & 0.53 & 24.8 & 0.40 & 3.5 & 0.72 \\
\hline $\mathrm{TN}^{n}$ & 53.2 & 0.12 & 39.3 & 0.35 & 66.1 & 0.10 & 25.2 & 0.55 \\
\hline $\mathrm{PO}_{4}$-P & 42.3 & 0.36 & -25.3 & 0.66 & -5.6 & 0.57 & -28.9 & 0.67 \\
\hline $\mathrm{TP}$ & 33.5 & 0.64 & 30.1 & 0.58 & 61.1 & -0.04 & 21.0 & 0.68 \\
\hline
\end{tabular}

Explanations: $\mathrm{TN}=$ total nitrogen, $\mathrm{TP}=$ total phosphorus.

Source: own study.

(with extremes and outliers) across all monitoring points included in calibration and validation. As can be noticed in the PBIAS and KGE graphs among the unsatisfactory performing variables few monitoring points in the Upper Narew and in the Barycz can be found $\left(\mathrm{NO}_{3}-\mathrm{N}\right.$ and sediment in the Upper Narew or $\mathrm{PO}_{4}-\mathrm{P}$ and sediment in the Barycz catchment).

\section{COMPARISON OF SIMULATIONS BETWEEN CATCHMENTS}

After calibration and validation process models were run for the time period 1999-2010 in order to compare the contaminant loads originating from different sources between catchments. Figure 6 presents water and sediment yield and inland emission of total nitrogen and phosphorus from sub-basins into the streams in both catchments. Mean annual water yield is comparable in the Upper Narew and the Barycz (150 and $130 \mathrm{~mm}$ respectively), unlike other variables. Sediment specific loads are significantly higher in the Upper Narew $\left(0.24 \mathrm{~kg} \cdot \mathrm{ha}^{-1}\right.$ on average $)$ compared to the Barycz $\left(0.05 \mathrm{~kg} \cdot \mathrm{ha}^{-1}\right)$, which can be explained by higher rain erosion, higher surface runoff, shorter growing period combined with lower percentage of winter crops covering soils in autumn and winter. Total nitrogen and phosphorus specific loads quite the opposite, are higher in the Barycz ( $\mathrm{TN}=4.1$ $\mathrm{kg} \cdot \mathrm{ha}^{-1}, \mathrm{TP}=0.08 \mathrm{~kg} \cdot \mathrm{ha}^{-1}$ ) than in the Upper Narew
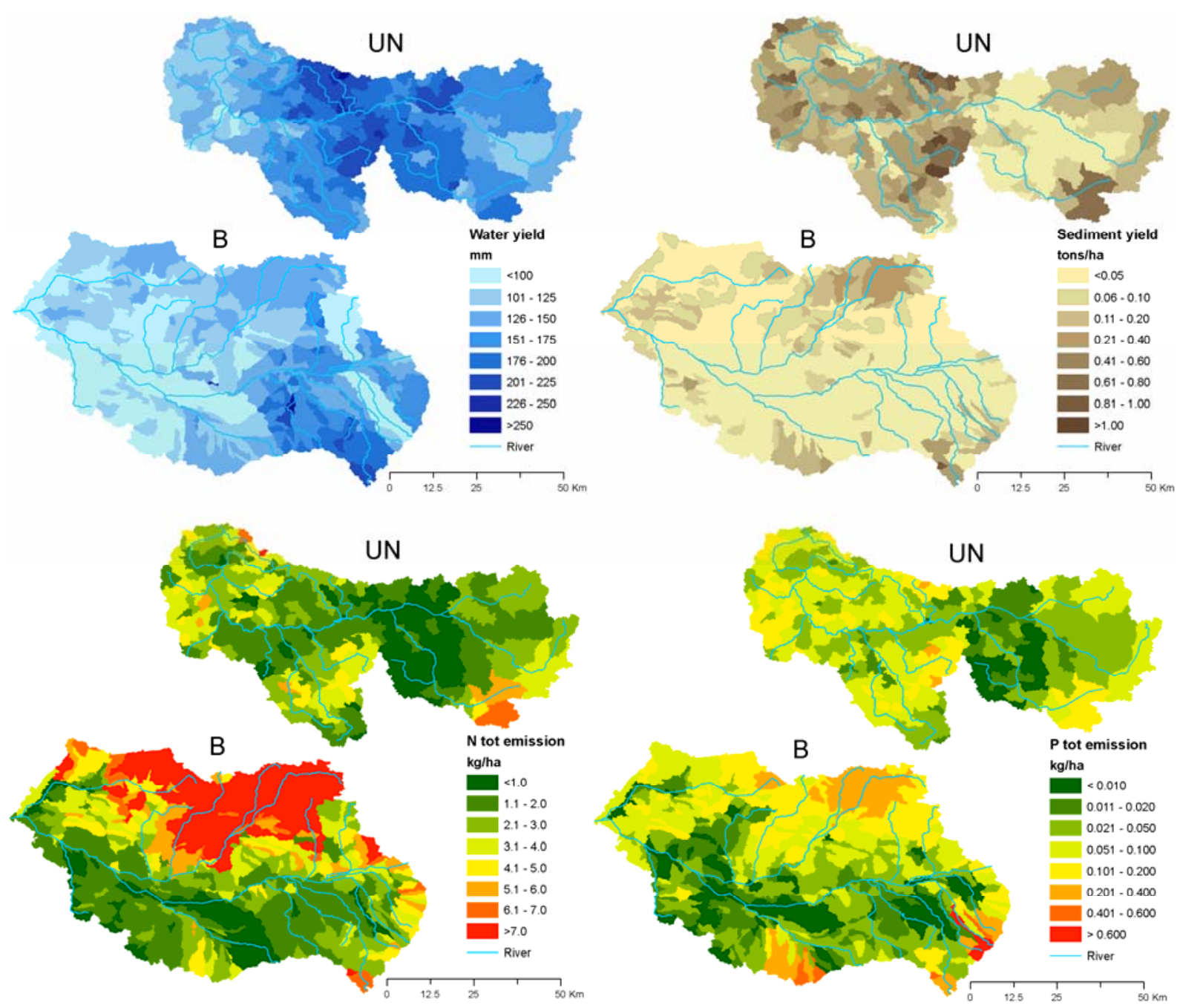

Fig. 6. Simulated water yield and loadings of: sediment, total nitrogen (Ntot) and total phosphorus (Ptot) average yearly values for time period 1999-2010 (B = Barycz, UN = Upper Narew); source: own study 
$\left(\mathrm{TN}=2.2 \mathrm{~kg} \cdot \mathrm{ha}^{-1}, \mathrm{TP}=0.06 \mathrm{~kg} \cdot \mathrm{ha}^{-1}\right)$. All maps indicate a high spatial variability of pollution emission. Notably, the northern part of the Barycz catchment (the Orla and Polski Rów sub-catchments) is distinct in terms of high magnitude of $\mathrm{NO}_{3}$ emission, which is well explicable as it has been designed as the Nitrate Vulnerable Zone.

Among the main pollution sources agriculture, WWTPs, septic systems and atmospheric deposition were distinguished. To ensure a coherent comparison, a number of model simulations has been made, in which particular sources were disabled, and their contribution was then estimated as the difference between loads calculated in the baseline scenario and scenario with a disabled source. For simplicity this difference was calculated only at the main catchment outlets. Comparison of the specific loads of contaminants at the catchments outlets (Tab. 8) clearly indicates that beside the sediment loads, all of them are significantly higher in the Barycz than in Upper Narew catchment. Table 8 also presents the share of each defined pollution source in the models of both catchments. In general, agriculture is the main source of all contaminants loads ranging its share from $57 \%$ to $86 \%\left(\mathrm{PO}_{4}-\mathrm{P}\right)$. Slight differences are visible comparing the catchments in terms of atmospheric deposition which in the Upper Narew is responsible for two times higher contribution in $\mathrm{NO}_{3}-\mathrm{N}$ loads than in the Barycz. On the other hand, WWTPs' share in $\mathrm{PO}_{4}-\mathrm{P}$ loads is three times higher in the Barycz than in the Upper Narew which is obvious due to their number in the catchment (41). In both catchments septic systems have minor impact on contaminants loads not exceeding 3\% share in the total specific loads. Zero values of phosphorus loads from septic systems are due to the fact that the effluent from septic tanks is disposed to a soil layer but due to limited mobility of phosphorus in SWAT it does not reach the stream.

Table 8. Contaminants loads $\left(\mathrm{kg} \cdot \mathrm{ha}^{-1}\right)$ at the catchments outlets for different sources and percentage share of the pollution source in the total specific load

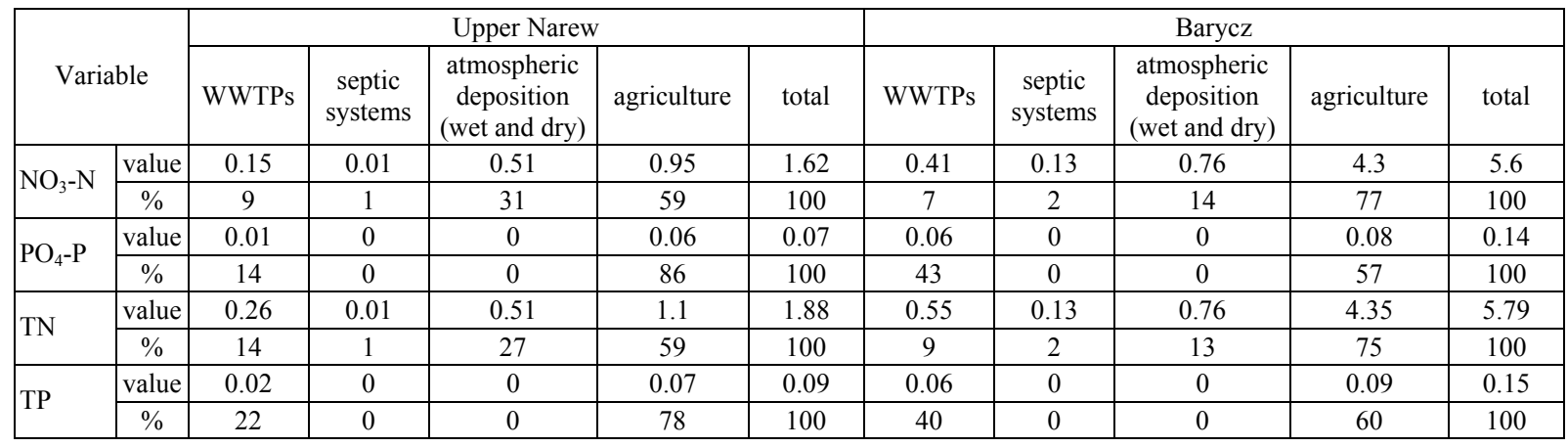

Source: own study.

\section{DISCUSSION}

\section{GLOBAL VS. LOCAL PARAMETERS SENSITIVITIES}

There was a significant issue with calibrating sediment in the Upper Narew catchment. The Upper Narew River is characterized by an extremely low channel slopes, not exceeding 0.0002, while its main tributaries have higher slopes (mean 0.001) and significantly different topographical setting. Sensitivity analysis of sediment parameters clearly indicated that the most powerful impact on mean simulated loads and $\mathrm{KGE}$ resulted from changing the global parameters (e.g PRF BSN, ADJ PKR, SPCON, SPEXP Table 4), while sensitivity of local parameters was much lower. In consequence, adjusting the global parameters to achieve higher objective function values for stations located on the main river caused deterioration of all statistics for the tributaries (and vice-versa). This in turn led to a situation, in which no compromise solution was possible and hence, the priority of calibration was assigned to the main river ( 5 stations) rather than tributaries (3 stations). Similar limitation resulting from inability of the model to vary some parameters that are designated on a watershed level basis was raised by WhITE, CHAUBEY [2005]. They even suggested that it might be more appropriate to build separate SWAT models for calibration areas that possess substantial physical differences that would benefit from greater spatial variability in parameterization.

\section{SIMULTANEOUS CALIBRATION OF DIFFERENT FORMS OF N AND P}

Two pools of nitrogen (nitrate and total) and two pools of phosphorus (mineral and total) were calibrated in sequence using the same set of parameters in each catchment. In this indirect way a control over $\mathrm{N}$ and $\mathrm{P}$ forms other than nitrate and mineral $\mathrm{P}$ (i.e. $\mathrm{NH}_{4}-\mathrm{N}, \mathrm{NO}_{2}-\mathrm{N}$ and organic $\mathrm{N}$ for nitrogen and organic $\mathrm{P}$ for phosphorus) was kept. This approach required controlling, in each iteration, goodness-of-fit measures of both of nitrogen and phosphorus pools. It was often the case that achieving high objective function values of total forms resulted in lower values of other forms (and vice versa). Hence, a different approach based on one-at-a-time calibration of each constituent separately (first nitrates, second total ni- 
trogen loads and after that mineral phosphorus and total phosphorus) was tested, which showed better results for mineral and total pools of nutrients considered separately. However, it required adjusting calibration parameters at different levels for the variables each time. To get one comprehensive model simulating properly both nitrogen and phosphorus pools calibration and validation processes required a simultaneous approach. This indeed resulted in a bit worse goodness-of-fit measures comparing to what could be obtained for individual calibration (separating mineral from total pools), but it was the only solution to create a complex water quality model for all contaminants' pools. Similar problem was encountered by SANTHI et al. [2001] with nitrogen pools calibration where for the same time period simulations of mineral pools against observation were overestimated and simulations of organic pools where underestimated at corresponding dates.

\section{SIMULATION OF WATER QUALITY IN RESERVOIRS}

Water quality calibration downstream of Siemianówka reservoir located on the Upper Narew turned out to be another challenging issue. The
SWAT model assumes the reservoir is completely mixed, and ignores its stratification using simplified mass balance equations [NEITSCH et al. 2011]. Nutrient transformations are limited to the their removal by settling and the settling rates (NSETLR1, NSETLR2, PSETLR1, PSETLR2 - Table 5 and 6) are the main calibration parameters. These parameters, however, control all pools of nitrogen and phosphorus in the same way, regardless of the fact that nutrient transformations in reservoirs can be more complex and they can affect different forms in different ways. The adjustment of one of them caused mismatching in the other. During summer months concentrations of nitrates are extremely low $\left(<0.002 \mathrm{mg} \cdot \mathrm{dm}^{-3}\right)$ and to reflect this phenomenon in the model NSETLR1 has to be high. Unlike the nitrate-nitrogen, total nitrogen concentrations are significantly higher during summer and to simulate this properly in the model NSETLR1 has to be much lower than when adjusted for nitrates. This inconsistency unavoidably made the calibration of both pools of nitrogen at satisfactory level impossible and required a compromise solution. Figure 7 depicts the simulated vs observed $\mathrm{NO}_{3}-\mathrm{N}$ and $\mathrm{TN}$ loads in the Bondary water quality monitoring point (downstream of the Siemianówka reservoir).

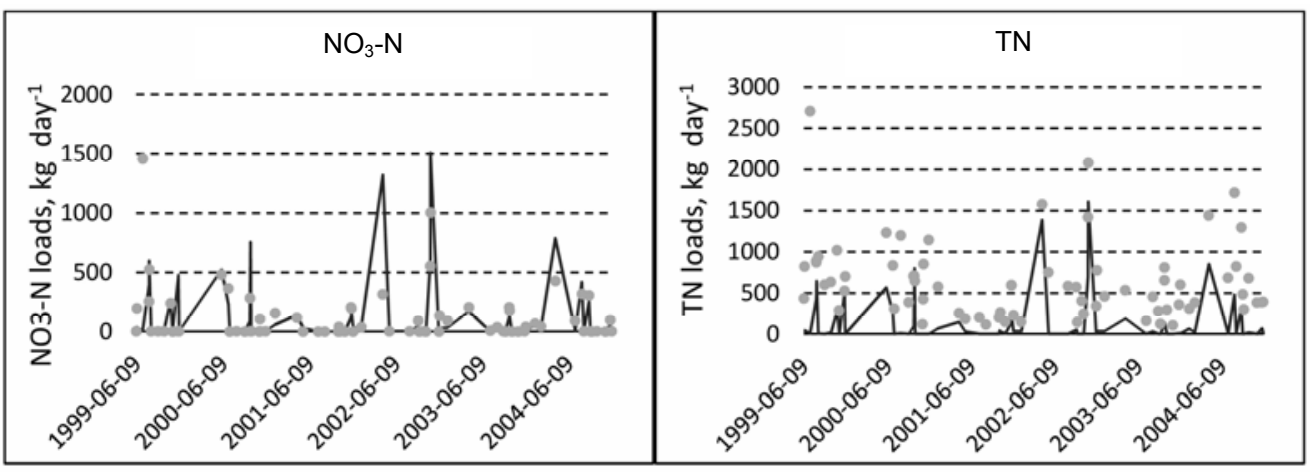

Fig. 7. Calibration plots for Bondary water quality monitoring point (downstream to the Siemianówka reservoir) for different pools of nitrogen (black lines $=$ simulated, grey dots $=$ observed values); $\mathrm{TN}=$ total nitrogen; source: own study

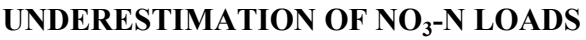 IN WINTER}

During calibration process of $\mathrm{NO}_{3}-\mathrm{N}$ a specific trend was noted in the observed dataset, i.e. high peaks of nitrate-nitrogen loads in winter months (January-February) in both catchments. For every year in model performance these winter peaks were significantly underestimated as no major source of nitrogen could be defined for that period coming from the environment or any recognized artificial source. A hypothesis explaining this phenomenon concerned a popular farmers practices of exporting manure and slurry directly into the fields once the capacity of farming buildings and tanks was exceeded during winter season (January, February) [TWARDY 1998]. BANASZUK [2007] emphasized the fact that snow melting constitutes a critical source of mineral elements (especially nitrates). Application of fertilizers on frosted bare ground causes significant nitrogen leaching and surface runoff [TWARDY, SMOROŃ 2011]. In order to verify this hypothesis, management operation schedule was modified in the Upper Narew model to artificially express these practices at the catchment scale. The HUSC (Fraction of total base zero heat units at which operation takes place) parameter was modified in such a way that spring fertilizer application was accelerated by ca. 2 months, so that it occurred in the period of underestimated $\mathrm{NO}_{3}$ peaks. The model was run with modified settings, showing an improved performance achieved by significantly higher simulated loads of nitrogen from agricultural HRUs in winter due to excess fertilization (Fig. 8). Hence, these results clearly indicate that these winter peaks of nitrate loads that were missed by the model were most probably caused by farmers and their common practices of exporting manure into the fields. 


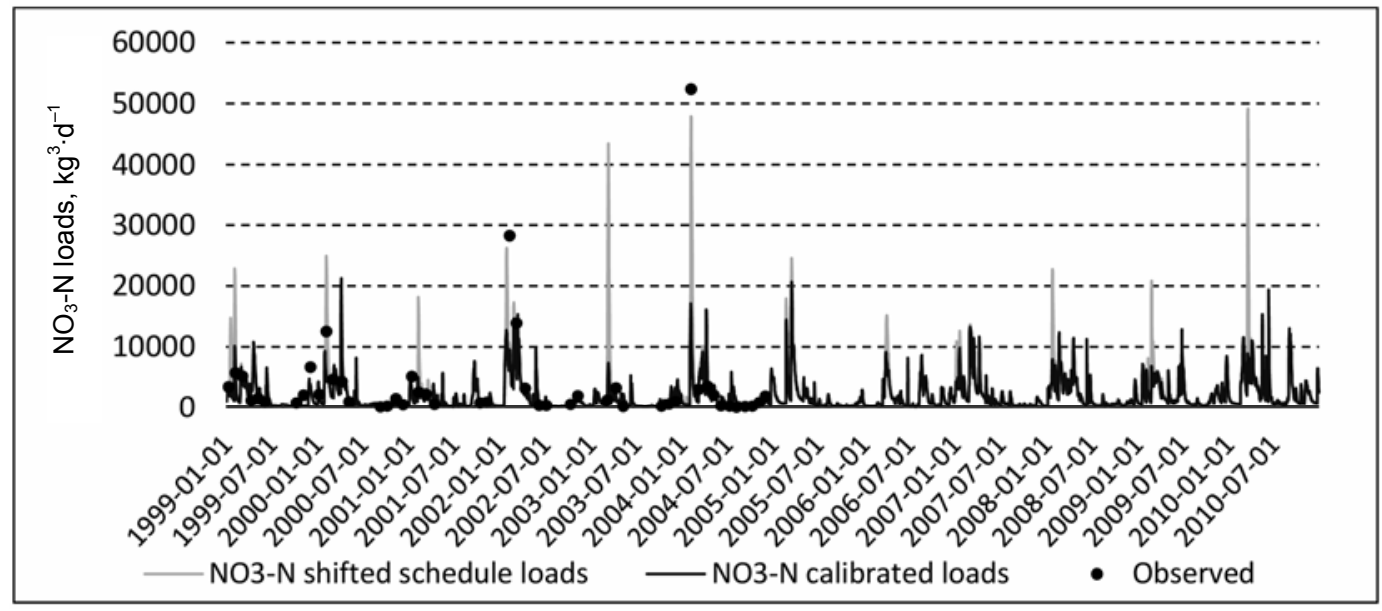

Fig. 8. $\mathrm{NO}_{3}-\mathrm{N}$ daily loads at the Upper Narew catchment outlet for actual and shifted agricultural management schedules; source: own study

\section{CONCLUSIONS}

This study constitutes a detailed summary of an application of the SWAT water quantity and quality model in two contrasting meso-scale catchments in Poland. Multi-site, multi-variable calibration approach allowed to spatially quantify water yield, sediment and nutrient loads, indicate areas of special concern in terms of pollution, as well as estimate contribution of pollution from different sources. Good model performance of high nitrate loadings in the northern part of the Barycz catchment corresponding with designed Nitrate Vulnerable Zones proves spatial accuracy of simulations. Despite the differences in management and intensification of human pressures, agriculture was recognized as the most important source of pollution in both catchments. Therefore, in order to reduce nutrient loadings to surface water system in future, special attention should be drawn to measures oriented on agricultural practices.

Spatial calibration and validation approach gave varied results ranging from very good to rather poor for individual monitoring points and variables. Comparison of statistics between two catchments shows generally higher values for the Barycz than for the Upper Narew catchment which can be partially explained by using global (less accurate) datasets in the Upper Narew model setup.

Development of such comprehensive models, simulating water quantity and quality at relatively fine scale cannot happen without problems that should be expressly stated. Some of the issues resulted from model limitations i.e. global vs. local parametrization or simulation of different pools of water quality parameters in reservoirs and streams, while other resulted from the input uncertainty (i.e. differences between defined management operations and the reality), which resulted in a severe underestimation of $\mathrm{NO}_{3}-\mathrm{N}$ loads in winter. This study shows how the SWAT model can be useful for the quantification of pollution sources and indication of areas of special concern but also exposes difficulties and potential issues that might be encountered in similar research. Importantly, this study sets the ground for the planned scenario modelling work, notably projecting effects of climate and land use change on water quantity and quality. Future work should also include development of the SWAT model components for reasonable representation of fish pond effects.

\section{ACKNOWLEDGEMENTS}

Support of the project CHASE-PL (Climate change impact assessment for selected sectors in Poland) of the Polish-Norwegian Research Programme operated by the National Centre for Research and Development (NCBiR) under the Norwegian Financial Mechanism 2009-2014 in the frame of Project Contract No. Pol Nor/200799/90/2014 is gratefully acknowledged. The Institute of Meteorology and Water Management - State Research Institute (IMGW-PIB) is kindly acknowledged for providing the hydrometeorological data used in this work.

\section{REFERENCES}

ABBASPOUR K. 2015. SWAT-CUP2: SWAT Calibration and Uncertainty Programs - a user manual. Duebendorf, Switzerland. Eawag: Swiss Federal Institute of Aquatic Science and Technology pp. 95.

Abbaspour K.C., Rouholahnejad E., Vaghefi S., SRinivasan R., YANG H., Kløve B.A. 2015. Continental-scale hydrology and water quality model for Europe: Calibration and uncertainty of a high-resolution large-scale SWAT model. Journal of Hydrology. Vol. 524 p. 733-752.

Al-Dousari A., Milewski A., Din S.U., Ahmed M. 2010. Remote sensing inputs to SWAT model for groundwater recharge estimates in Kuwait. Advances in Natural and Applied Sciences. Vol. 4. Iss. 1 p. 71-77.

BANASZUK P. 2007. Wodna migracja składników rozpuszczonych do wód powierzchniowych w zlewni górnej Narwi [Water migration of dissolved particles into surface waters in the Upper Narew Catchment]. Białystok. Wydaw. P.Biał. pp. 182.

Berezowski T., SzczeŚniaK M., Kardel I., Michąowski R., Okruszko T., Mezghani A., Piniewski M. 2016. CPLFD-GDPT5: High-resolution gridded daily precipitation and temperature data set for two largest Polish 
river basins. Earth System Science Data. Vol. 8. Iss. 1 p. $127-139$.

BROWN L.C., BARNWELl T.O. 1987. The Enhanced Stream Water Quality Models QUAL2E and QUAL2EUNCAS: Documentation and user manual. Cooperative Agreement No. 811883. Athens, Georgia. Environmental Research Laboratory, Office of Research and Development, U.S. Environmental Protection Agency pp. 189.

Brzozowski J., MiatKowski Z., Śliwiński D, SMARZyŃSKA K., ŚmieTANKa M. 2011. Application of SWAT model to small agricultural catchment in Poland. Journal of Water and Land Development. No. 15 p. 157-166.

Č́rkasova N., ERtürk A., Zemlys P., Denisov V., UmGiESSER G. 2016. Curonian Lagoon drainage basin modelling and assessment of climate change impact. Oceanologia. Vol. 58. Iss. 2 p. 90-102.

Daggupati P., Pai N., Ale S., Douglas-Mankin K.R.W., Zeckoski R., Jeong J., Parajuli P. B., Saraswat D., YousSEF M.A. 2015. A recommended calibration and validation strategy for hydrologic and water quality models. American Society of Agricultural and Biological Engineers. Vol. 58. Iss. 6 p. 1705-1719. DOI: 10.13031/trans.58.10712.

Dakhlalla A.O., PARAJUli P.B. 2016. Evaluation of the best management practices at the watershed scale to attenuate peak streamflow under climate change scenarios. Water Resources Management. Vol. 30. Iss. 3 p. 963-982.

DRABIŃSKI A., JAWECKI B., TOKARCZYK-DOROCIAK K. 2010. The role of carp fish ponds in the water management of the river basins. In: Multifunctionality in pond aquaculture in Poland. Perspectives and Prospects. Eds M. Cieśla, M. Kuczyński. Warszawa. Warsaw University of Life Sciences, Editorial House "Wieś Jutra" p. 24-29.

GAO L., Li D. 2014. A review of hydrological/water-quality models. Frontiers of Agricultural Science and Engineering. Vol. 1. Iss. 4 p. 267-276. DOI: 10.15302/J-FASE2014041.

Gupta H.V., Kling H., Yilmaz K.K., Martinez G.F. 2009. Decomposition of the mean squared error and NSE performance criteria: implications for improving hydrological modelling. Journal of Hydrology. Vol. 377 p. $80-91$.

GUS 2000. Bank danych lokalnych. Ochrona środowiska [Local data bank. Environmental protection] [online]. [Access 12.12.2015]. Available at: https://bdl.stat.gov. $\mathrm{pl} / \mathrm{BDL} /$ dane/podgrup/temat

GUS 2010. Bank danych lokalnych. Rolnictwo [Local data bank. Agriculture] [online]. [Access 10.10.2015]. Available at: https://bdl.stat.gov.pl/BDL/dane/podgrup/ temat

GUS 2015. Bank danych lokalnych. Ludność [Local data bank. Population] [online]. [Access 10.02.2016]. Available at: https://bdl.stat.gov.pl/BDL/dane/podgrup/temat

HARGREAVES G.H., SAMANI Z.A. 1982. Estimating potential evapotranspiration. Journal of the Irrigation and Drainage Division. Vol. 108. Iss. 3. Iss. 3 p. 225-230.

MarcinKowsKi P., PiniewSKi M., KARDEl I., GIEŁCZEWSKI M., OKRUSZKO T. 2013. Modelling of discharge, nitrate and phosphate loads from the Reda catchment to the Puck Lagoon using SWAT. Annals of Warsaw University of Life Sciences - SGGW. Land Reclamation. Vol. 45. Iss. 2 p. $125-141$.
MRiRW, MŚ 2004. Kodeks dobrej praktyki rolniczej [A code of good agricultural practice]. Warszawa. ISBN 83-88010-58-1 pp. 93.

Molina-Navarro E., Trolle D., Martínez-Pérez S., SASTRE-MERLín A., JEPPESEN E. 2014. Hydrological and water quality impact assessment of a Mediterranean limno-reservoir under climate change and land use management scenarios. Journal of Hydrology. Vol. 509 p. 354-366.

Neitsch S., Arnold J., Kiniry J., Williams J. 2011. Soil and Water Assessment Tool theoretical documentation version 2009. Tech. Rep. TR-406, Texas A\&M University. Retrieved 28 March, 2013. Available at: http://twri.tamu.edu/reports/2011/tr406.pdf

OstojSKi M.S., NiedBala J., ORLINSKA-WozNiaK P., WiLK P., Gębala J. 2014. Soil and Water Assessment Tool model calibration results for different catchment sizes in Poland. Journal of Environmental Quality. Vol. 43. No. 1 p. $132-144$.

OvERTON D.E. 1966. Muskingum flood routing of upland streamflow. Journal of Hydrology. Vol. 4 p. 185-200.

Pagliero L., Bouraouia F., Willems P., Diels J. 2014. Large-scale hydrological simulations using the Soil Water Assessment Tool, protocol development, and application in the Danube basin. Journal of Environmental Quality. Vol. 43. No. 1 p. 145-154.

PINIEWSKI M. 2012. Impacts of natural and anthropogenic conditions on the hydrological regime of rivers: A Narew River Basin case study. Doctoral thesis. Warszawa. IMGW-PIB pp. 194.

PinieWSKi M., KARDEL I., GIEŁCZEWSKI M., MARCINKOWSKI P., OKRUSZKO T. 2014. Climate change and agricultural development: Adapting Polish agriculture to reduce future nutrient loads in a coastal watershed. Ambio. Vol. 43. Iss. 5 p. 644-660. DOI 10.1007/s13280-013-0461-z.

PINIEWSKI M., MARCINKOWSKI P., KARDEL I., GIEŁCZEWSKI M., IZYDORCZYK K., FrĄTCZAK W. 2015. Spatial quantification of non-point source pollution in a meso-scale catchment for an assessment of buffer zones efficiency. Water. Vol. 7. Iss. 5 p. 1889-1920. DOI: 10.3390/ w7051889.

Piniewski M., SzczeŚniak M., Kardel I., Berezowski T., Okruszko T., Srinivasan R., Schuler D. V., KunDZEWICZ Z.W. 2016. Modelling water balance and streamflow at high resolution in the Vistula and Odra basins. Hydrological Sciences Journal (in review).

Santhi C., ARnold J.G., Williams J.R., Dugas W.A., SRINIVASAN R., HAUCK L.M. 2001. Validation of the SWAT model on a large river basin with point and nonpoint sources. Journal of the American Water Resources Association. Vol. 37. Iss. 5 p. 1169-1188.

Sheshukov A.Y., Douglas-Mankin K.R., Sinnathamby S., DagGupati P. 2016. Pasture BMP effectiveness using an HRU-based subarea approach in SWAT. Journal of Environmental Management. Vol. 166 p. 276-284.

SMARZYŃSKA K., MiATKOWSKI Z. 2016. Calibration and validation of SWAT model for estimating water balance and nitrogen losses in a small agricultural watershed in central Poland. Journal of Water and Land Development. No. 29 p. 31-47.

SZCZEŚNIAK M., PINIEWSKI M. 2015. Improvement of hydrological simulations by applying daily precipitation interpolation schemes in meso-scale catchments. Water. Vol. 7. Iss. 2 p. 747-779. DOI: 10.3390/w7020747.

ŚMIETANKA M. 2014. The influence of permanent grasslands on nitrate nitrogen loads in modelling approach. 
Journal of Water and Land Development. No. 21 p. 6370.

TOKARCZYK-DOROCIAK K., SZEWRAŃSKI S., ŻMUDA R. 2011. The influence of agriculture and water balance on the landscape variety of the Barycz valley. Infrastructure and Ecology of Rural Areas. Vol. 10 p. 187-196.

TWARDY S. 1998. Wpływ obornika składowanego na łące na jakość wód powierzchniowych spływających po sto$\mathrm{ku}$ [Influence of farmyard manure stored on the meadow on quality of surface waters flowing over mountainside]. Pieniny - Przyroda i Człowiek. Nr 6 p. 105-110.

Twardy S., SMORoŃ S. 2011. Wpływ obornika owczego składowanego na zadarnionym stoku górskim na jakość wód spływających [The effect of sheep manure stored on grassy mountain slope on the quality of runoff waters]. Woda-Środowisko-Obszary Wiejskie. T. 11. Z. 2 (34) p. 165-171.

Tyszewski S., OKruszko T., PusŁowska D. 1997. Propozycja metodyki określania sposobu wykorzystania zasobów wodnych zlewni o szczególnych walorach przyrodniczych na przykładzie górnej Narwi i Supraśli. W: Ochrona jakości i zasobów wodnych. Podstawy racjonalnej gospodarki wodą [Methodology suggested for determination of water resources use in a catchment of unique natural qualities - on an example of the Upper
Narew and Supraśl Rivers. In: Water quality and water resources protection. Principles of the rational water management]. Materiały Ogólnopolskiego Seminarium Naukowo-Technicznego. Zakopane-Kościelisko, październik 1996. Zakopane-Kościelisko. PZiTS p. 53-73.

Van Griensven A., Ndomba P., Yalew S., Kilonzo F. 2012. Critical review of SWAT applications in the upper Nile basin countries. Hydrology and Earth System Sciences. Vol. 16 p. 3371-3381.

White K.L., Chaubey I. 2005. Sensitivity analysis, calibration, and validations for a multisite and multivariable SWAT model. Journal of the American Water Resources Association. Vol. 41. Iss. 5 p. 1077-1089.

WILLIAMS J.R. 1990. The erosion-productivity impact calculator (EPIC) model: A case history. Philosophical Transactions: Biological Sciences. Vol. 329 (1255) p. $421-428$.

WiLliams J.R., BERNDT H.D. 1977. Sediment yield prediction based on watershed hydrology. Transactions of the ASAE. Vol. 20. Iss. 6 p. 1100-1104.

WoZNicki S.A., NeJAdHASHEMi A.P., ABOUAli M., HeRman M.R., Esfahanian E., HamaAmin Y.A., Zhang Z. 2016. Ecohydrological modeling for large-scale environmental impact assessment. Science of the Total Environment. Vol. 543 p. 274-286.

\section{Pawel MARCINKOWSKI, Mikolaj PINIEWSKI, Ignacy KARDEL, Raghavan SRINIVASAN, Tomasz OKRUSZKO}

\section{Wyzwania w modelowaniu ilości i jakości wód w dwóch kontrastowych zlewniach w Polsce}

\section{STRESZCZENIE}

W niniejszej pracy przedstawiono zastosowanie modelu SWAT (Soil and Water Assessment Tool) w dwóch zlewniach w Polsce (Górnej Narwi i Baryczy), kontrastowych pod względem antropopresji w odniesieniu do ilości i jakości wód. Głównym celem była przestrzenna kalibracja i weryfikacja modelu w zakresie przepływów dobowych, ładunków zawiesiny i biogenów oraz dyskusja nad wyzwaniami napotkanymi w trakcie procesu kalibracji. Wyniki przestrzennej (wielopunktowej) kalibracji i weryfikacji są zróżnicowane - od dobrych (przepływ dobowy), poprzez akceptowalne (zawiesina, azot i fosfor w większości punktów monitoringu), do złych (pojedyncze punkty monitoringu dla każdej ze zmiennych). Skalibrowany model umożliwił przestrzenną kwantyfikację warstwy odpływu, ładunków zawiesiny i biogenów oraz wskazanie obszarów szczególnie narażonych na zanieczyszczenia z różnych źródeł, jednocześnie wskazując rolnictwo jako główne źródło. Podczas kalibracji modelu napotkano następujące problemy: (1) identyfikacja parametrów globalnych w odniesieniu do lokalnych, (2) symulacja różnych form parametrów jakościowych w zbiornikach wodnych i ciekach oraz (3) niedoszacowanie ładunków azotanów w okresie zimowym spowodowane praktykami rolniczymi. Dyskusja nad poruszonymi aspektami umożliwi innym użytkownikom modelu SWAT lepsze zrozumienie mechanizmu wielopunktowej i wieloparametrycznej kalibracji.

Słowa kluczowe: biogeny, kalibracja modelu, model SWAT, modelowanie ilości wód, modelowanie jakości wód, weryfikacja modelu 